\title{
Cloning and Expression of a Cytosolic HSP90 Gene in Chlorella vulgaris
}

\author{
Zhengyi Liu, ${ }^{1}$ Lei Zhang, ${ }^{2}$ Yang Pu, ${ }^{2}$ Zhaopu Liu, ${ }^{1}$ Zhiling Li, ${ }^{3}$ \\ Yushan Zhao, ${ }^{3}$ and Song Qin ${ }^{1}$ \\ ${ }^{1}$ Key Lab of Marine Biology in Jiang Su, College of Resources and Environmental Science, \\ Nanjing Agricultural University, Nanjing 210095, China \\ ${ }^{2}$ Yantai Institute of Coastal Zone Research, Chinese Academy of Sciences, Yantai 264003, China \\ ${ }^{3}$ Shandong Oriental Ocean Sci-Tech Co., Ltd., Yantai 264003, China \\ Correspondence should be addressed to Song Qin; sqin@yic.ac.cn
}

Received 4 December 2013; Accepted 16 January 2014; Published 13 March 2014

Academic Editor: Hanzhi Lin

Copyright (C) 2014 Zhengyi Liu et al. This is an open access article distributed under the Creative Commons Attribution License, which permits unrestricted use, distribution, and reproduction in any medium, provided the original work is properly cited.

\begin{abstract}
Heat shock protein 90 (HSP90), a highly conserved molecular chaperone, plays essential roles in folding, keeping structural integrity, and regulating the subset of cytosolic proteins. We cloned the cDNA of Chlorella vulgaris HSP90 (named CvHSP90) by combining homology cloning with rapid amplification of cDNA ends (RACE). Sequence analysis indicated that CvHSP90 is a cytosolic member of the HSP90 family. Quantitative RT-PCR was applied to determine the expression level of messenger RNA (mRNA) in CvHSP90 under different stress conditions. C. vulgaris was kept in different temperatures $\left(5-45^{\circ} \mathrm{C}\right)$ for $1 \mathrm{~h}$. The $\mathrm{mRNA}$ expression level of CvHSP90 increased with temperature from 5 to $10^{\circ} \mathrm{C}$, went further from 35 to $40^{\circ} \mathrm{C}$, and reached the maximum at $40^{\circ} \mathrm{C}$. On the other hand, for C. vulgaris kept at $35^{\circ} \mathrm{C}$ for different durations, the mRNA expression level of CvHSP 90 increased gradually and reached the peak at $7 \mathrm{~h}$ and then declined progressively. In addition, the expression level of CvHSP90 at 40 or 45 in salinity (\%o) was almost fourfold of that at 25 in salinity (\%o) for $2 \mathrm{~h}$. Therefore, CvHSP90 may be a potential biomarker to monitor environment changes.
\end{abstract}

\section{Introduction}

Heat shock proteins (HSPs) that first described in Drosophila melanogaster [1], are evolutionarily conserved protein families which are ubiquitous in all eukaryotic organisms. HSPs are essential for cells under both normal and stressed conditions as they participate in diverse processes ranging from cellular homeostasis and signal transduction to development [2]. In addition, HSPs also play key roles in defense responses against various environmental stresses that could potentially damage the cellular and molecular structures in the cells [3]. Therefore, HSPs are highly expressed in all organisms and are one of the most abundant proteins, contributing to 1$2 \%$ of total cellular proteins under normal conditions [4]. According to molecular weight, HSPs are mainly classified into six families including HSP40, HSP60, HSP70, HSP90, HSP100, and the small HSPs [5].
Among HSP families, heat shock protein 90 (HSP90) is highly conserved member. It is confirmed to locate in different cellular compartments including the chloroplasts, mitochondria, cytosol, nucleoplasm, and endoplasmic reticulum [6]. Under normal conditions, HSP90's diverse roles in biological processes include regulating cellular physiology, signal transduction, and protein folding, degradation, and transportation [2,7-9]. And it also can be regulated by various environmental stresses such as heat, salinity, desiccation, light, heavy metal, and arsenite stresses [10-13].

Influenced by cyclic tide, algae mainly living in intertidal zone are periodically exposed to a variety of potentially stressful factors including heat or cold shock, high light, and desiccation [14]. To understand the resistant mechanism, the expression of HSPs genes have been investigated in some macroalgae such as Chondrus, Porphyra, Undaria, Laminaria, Saccharina, Fucus, and Ulva [15-22] and a few microalgae 
TABLE 1: PCR primers used in this study.

\begin{tabular}{lcc}
\hline Primers & Sequence $\left(5^{\prime}-3^{\prime}\right)$ & Sequence information \\
\hline P1 & GNGTGTTCATCATGGACAAYTGYGA & Homology cloning primer \\
P2 & TTCATGATGCKYTCCATGTTNGC & Homology cloning primer \\
P3 & GCCCCTCAACATCTCCCGCG & $3^{\prime}$-RACE primer \\
P4 & ACCTGCCCCTCAACATCTCCC & $3^{\prime}$-RACE primer \\
adaptor & GGCACGCGTCGACTAGTAC & $3^{\prime}$-RACE primer \\
P5 & TTTTGTCCTCCTCGGTCTCG & $5^{\prime}$-RACE primer \\
P6 & GCCCTCCTTGGTCACGCTCA & $5^{\prime}$-RACE primer \\
Oligo(dG)-adaptor & GGCACGCGTCGACTAGTACG10 & $5^{\prime}$-RACE primer \\
P7 & GGCCAGTTCGGCGTGGGTTT & Real time gene primer \\
P8 & AAGCGACGGGTTGACGGTGT & Real time gene primer \\
P9 & AACTACGAGCTGCCAGACGG & Real time actin primer \\
P10 & GAAGACAAGACGATGCTGAGGG & Real time actin primer \\
M13-47 & CGCCAGGGTTTTCCAGTCACGAC & Sequencing primer \\
RV-M & GAGCGGATAACAATTTCACACAGG & Sequencing primer \\
\hline
\end{tabular}

such as Chlamydomonas and Haematococcus [23-27]. These studies indicate that the algal HSPs centrally function in resisting a wide variety of environmental stressors.

Chlorella vulgaris is a unicellular green alga growing in fresh water [28]. It can be used as live feed in fish aquaculture for its high content of proteins and fatty acids. In addition, because of its fast growth and low cost, $C$. vulgaris becomes a promising candidate bioreactor for large-scale production of value-added proteins [29]. C. vulgaris has important economical and ecological values but often confronts environmental adversities, including high temperature and high salinity. Therefore, it is often used as a eukaryotic model in studies on stress responses [30]. However, the role of HSPs in adverse stress resistance mechanism of $C$. vulgaris is yet to be performed.

To better understand the mechanism of response by C. vulgaris to different types of environmental stimulation, we obtained a HSP90 complementary DNA (cDNA) of $C$. vulgaris by combining homology cloning with rapid amplification of cDNA ends (RACE) approaches, analyzed in bioinformatics the structural features, homologous relationship, and phylogenetic position of CvHSP90, and investigated the messenger RNA (mRNA) expression levels of CvHSP90 under different stress conditions, using real-time quantitative RT-PCR (qRT-PCR).

\section{Materials and Methods}

2.1. Sample Collection and Treatment. Chlorella vulgaris was presented from Institute of Oceanology, Chinese Academy of Sciences, and then the Chlorella was grown in Erlenmeyer flasks in F/2 medium that was filter-sterilized through $0.22 \mu \mathrm{m}$ filters (Millipore, USA). Cultures in liquid medium or on plate were grown at $20^{\circ} \mathrm{C}$ in an artificial climate incubator. Cool-white fluorescent tubes were used to provide irradiance at $200 \mu \mathrm{mol}$ photons $\mathrm{m}^{-2} \mathrm{~s}^{-1}$ in a long-daylight scheme (12:12 h light: dark).
In addition, C. vulgaris was kept in $40^{\circ} \mathrm{C}$ for $1 \mathrm{~h}$ for extracting total RNA and cloning full-length cDNA of CvHSP90 gene. In our heat shock temperature treatment, C. vulgaris was kept in different temperatures $(5,10,15,20,25,30,35$, 40 , and $45^{\circ} \mathrm{C}$ ) for $1 \mathrm{~h}$ to investigate the thermal effect on the expression level of CvHSP90 mRNA. In heat shock time treatment, C. vulgaris was kept at $35^{\circ} \mathrm{C}$ for different times $(0 \mathrm{~h}, 1 \mathrm{~h}, 2 \mathrm{~h}, 3 \mathrm{~h}, 4 \mathrm{~h}, 5 \mathrm{~h}, 6 \mathrm{~h}, 7 \mathrm{~h}, 8 \mathrm{~h}, 9 \mathrm{~h}, 10 \mathrm{~h}, 11 \mathrm{~h}$, and $12 \mathrm{~h}$, resp.) to investigate the effects of heat shock times on expression level of CvHSP90 mRNA. In salt concentration challenge treatments, C. vulgaris was kept at $20^{\circ} \mathrm{C}$ in different salt concentrations $(0,5,10,15,20,25,30,35,40$, and 45 in $\%$ ) for $2 \mathrm{~h}$ to investigate the effects of salt challenges on expression level of CvHSP90.

2.2. RNA Extraction. Total RNA extraction from C. vulgaris was performed using the TRIzol reagent (Invitrogen). The cDNA first-strand was synthesized based on M-MLV RT usage information (Promega) using RQI DNase (Promega)treated total RNA as template. cDNA mix was diluted to $1: 50$ and stored at $-80^{\circ} \mathrm{C}$ for subsequent fluorescent real-time PCR.

2.3. CvHSP90 cDNA Cloning. To amplify the partial fragment of CvHSP90 gene from Chlorella vulgaris, two homologous cloning primers P1 and P2 were designed based on the conserved sequence of known HSP90s (Table 1). PCR was performed in a $25 \mu \mathrm{L}$ reaction volume containing $2.5 \mu \mathrm{L} 10 \mathrm{X}$ PCR buffer, $2 \mu \mathrm{L}$ dNTP $\left(2.5 \mathrm{mmol} \mathrm{L}^{-1}\right), 1 \mu \mathrm{L}$ of each primer $\left(10 \mu \mathrm{mol} \mathrm{L}^{-1}\right), 0.2 \mu \mathrm{L}(1 \mathrm{U})$ of Taq polymerase (Promega), $1 \mu \mathrm{L}$ of cDNA template, and $17.3 \mu \mathrm{L}$ of PCR-grade water. The PCR temperature profile was $94^{\circ} \mathrm{C}$ for 5 min followed by 33 cycles of $94^{\circ} \mathrm{C}$ for $1 \mathrm{~min}, 56^{\circ} \mathrm{C}$ for $1 \mathrm{~min}, 72^{\circ} \mathrm{C}$ for $1 \mathrm{~min}$, and a final extension step at $72^{\circ} \mathrm{C}$ for $10 \mathrm{~min}$. The interesting fragment (745 bp) was excised and purified as per agarose gel DNA fragment recovery kit (TaKaRa), cloned into pMD-18T vector (TaKaRa), and sequenced (Sangon, Shanghai, China). 
To clone the full-length cDNA of CvHSP90, four specific primers, sense primers $\mathrm{P} 3$ and $\mathrm{P} 4$, and reverse primers $\mathrm{P} 5$ and P6 (Table 1) were designed based on the partial sequence amplified. Nested PCR strategy was applied to clone the $3^{\prime}$ end of CvHSP90 using sense primer P3, P4, and reverse primer adapter, while sense primer oligo(dG)-adaptor and reverse primer P5, P6 were used to obtain the $5^{\prime}$ end of CvHSP90. PCR amplification was performed using the same reaction system as described before. The PCR products were cloned into the pMD18-T simple vector (TaKaRa) and sequenced bidirectionally with primers M13-47 and RV-M (Table 1). The sequencing results were verified for cluster analysis.

2.4. Sequence Analysis of CvHSP90. CvHSP90 cDNA sequence was analyzed in the BLAST algorithm at National Centre for Biotechnology Information (http://www.ncbi.nlm .nih.gov/blast) and the deduced amino acid sequence was analyzed with the Expert Protein Analysis System (http:// www.expasy.org/). Characteristic domains or motifs were identified using the PROSITE profile database. Identity, similarity, and gap percentages were calculated using FASTA program. The Clustal W program (http://www.ebi.ac .uk/clustalw/) was used for multiple alignment of CvHSP90. An unrooted phylogenetic tree was constructed according to amino acid sequences of the selected HSP90 by using the neighbor-joining (NJ) algorithm embedded in MEGA 3.1 program (http://www.megasoftware.net/) [31] and the programs of Clustal X 1.83 [32]. The bootstrap trials were replicated 1000 times to derive the confidence value for the phylogeny analysis.

2.5. Quantitative Analysis of CvHSP90 mRNA Expression. mRNA expression level of CvHSP90 was investigated by real-time PCR amplification on a fast real-time PCR system (Applied Biosystem 7500). A product of $150 \mathrm{bp}$ from cDNA was amplified by two CvHSP90 gene-specific primers P7 and P8 (Table 1), and the PCR product was sequenced to verify the specificity of RT-PCR. An internal control, a 109 bp fragment, was amplified by two $\beta$-actin primers. The real-time PCR amplifications were carried out in a total volume of $20 \mu \mathrm{L}$ mixture containing $10 \mu \mathrm{L}$ SYBR Premix Ex Taq (TaKaRa, Tokyo, Japan), $2 \mu \mathrm{L} c \mathrm{DNA}, 0.4 \mu \mathrm{L}$ each forward and reverse primer $(10 \mu \mathrm{mol} / \mathrm{L}), 0.4 \mu \mathrm{L}$ ROX Reference Dye (50X), and $6.8 \mu \mathrm{L}$ PCR-grade water. The reactions conditions were $94^{\circ} \mathrm{C}$ for $5 \mathrm{~min}$, followed by $40 \mathrm{cycles}$ of $5 \mathrm{~s}$ at $94^{\circ} \mathrm{C}$, and $30 \mathrm{~s}$ at $60^{\circ} \mathrm{C}$. Five independent biological replicates were carried out. At the end of each PCR reaction, dissociation curve of amplicon was analyzed to confirm if only one PCR product was amplified and detected. After the PCR program, SDS software V2.01 (Applied Biosystems) was used to analyze the data, during which a baseline was set automatically for consistency. The expression level of CvHSP90 was analyzed by the $2^{-\Delta \Delta \mathrm{Ct}}$ method [33]. All data were expressed as mean \pm SE $(n=$ $5)$ in terms of relative mRNA. Furthermore, the data were analyzed by ANOVA (one-way analysis of variance) followed by an unpaired two-tailed $t$-test. Difference was considered significant at $P<0.05$.

\section{Results}

3.1. cDNA Cloning and Sequencing of CvHSP90 Gene. A CvHSP90 fragment (745 bp) was amplified by homologous cloning primers $\mathrm{P} 1$ and P2 and confirmed highly similar to other known HSP90s. Two pairs of CvHSP90-specific primers ( $\mathrm{P} 3-\mathrm{P} 4$ and $\mathrm{P} 5-\mathrm{P} 6)$ that designed in the above sequence were used to clone the full-length cDNA. RACE and nested PCR were performed to amplify the two fragments corresponding to the $3^{\prime}$ and $5^{\prime}$ end of the CvHSP90 cDNA. The full-length cDNA sequence of CvHSP90 was determined 3678 bp by cluster analysis of the above fragments.

3.2. Characterization of CvHSP90. The cDNA sequence of CvHSP90 was submitted in GenBank under accession number JQ655149. The full-length cDNA of CvHSP90 was $3678 \mathrm{bp}$, with a $107 \mathrm{bp} 5^{\prime}$ untranslated region (5'UTR), a 1459-bp $3^{\prime}$ untranslated region ( $3^{\prime} \mathrm{UTR}$ ) with a poly (A) tail, and a $2112 \mathrm{bp}$ open reading frame (ORF) encoding a polypeptide that contained 703 amino acids with estimated molecular mass of $80.71 \mathrm{kDa}$ and an estimated isoelectric point of 4.48. The five typical amino acid blocks of HSP90 protein family, (NKEIFLRE[L/I]ISN[A/S]SDALDKIR, LGTIARSGT, IGQFGVGFYSAYLVA[E/D], IKLYVRRVFI, G[V/I]VDSEDLPLNISRE) and the consensus MEEVD at the C-terminus were highly conserved as indicated in the CvHSP90 sequence (Figure 1) [34]. Meanwhile, SMART program revealed a typical histidine kinase-like ATPases domain in the position 27-182, which is ubiquitous in all HSP90 family members.

3.3. Homology Analysis of CvHSP90. Shown by Clustal W program, the deduced amino acid sequence of CvHSP90 shared high homology with those of other known HSP90s (Figure 2). For example, CvHSP90 shared 85\% similarity to Micromonas sp. RCC299 HSP90 (XP_002499727) and Micromonas sp. RCC299 HSP90 (XP_002499727), 79\% similarity to Haematococcus pluvialis HSP90 (JN627245), Chlamydomonas reinhardtii HSP90 (XP_001695264), and Volvox carteri $f$. nagariensis HSP90 (XP_002947115), and $78 \%$ similarity to Pennisetum glaucum HSP90 (ADP89125), Hordeum vulgare HSP90 (BAJ86355), Triticum aestivum HSP90 (ADF31758), Triticum urartu HSP90 (ADF31773), Vitis vinifera HSP90 (CAN62488), and Thellungiella halophila HSP90 (BAJ33984), and so forth (Table 2). Multiple sequence alignment exhibited high conservation between CvHSP90 and other known HSP90 proteins, especially in the regions of HSP90 family signatures (Figure 2).

To evaluate the molecular evolutionary relationships of CvHSP90 against other HSP90s, a phylogenetic tree based on the protein sequences (Figure 3 ) was constructed by neighbor-joining method. In the phylogenetic tree, the HSP90s are clustered into two major groups in the Streptophyta and Chlorophyta origin. CvHSP90 is clustered first with HSP90 from Mamiellophyceae (Micromonas sp. RCC299 and Micromonas pusilla CCMP1545) and then formed a sister group with those of Chlorophyta and further with those of Streptophyta. Relationships displayed in the phylogenic tree agree in overall with traditional taxonomy. 
1 GAGCTTGCGTTTCGCAGTCACTTTGCAAAAGAAGAACACGGCAACGTCAGACGTGCAGTG

1 M A E P E

61 TGGGATTAGATATTTGTGAAAACTAGAGCCTGGTGAGTAGCAAGCATGGCAGAGCCCGAG

$\begin{array}{lllllllllllllllllllll}6 & \mathrm{~T} & \mathrm{~F} & \mathrm{~A} & \mathrm{~F} & \mathrm{Q} & \mathrm{A} & \mathrm{E} & \mathrm{I} & \mathrm{N} & \mathrm{Q} & \mathrm{L} & \mathrm{L} & \mathrm{S} & \mathrm{L} & \mathrm{I} & \mathrm{I} & \mathrm{N} & \mathrm{T} & \mathrm{F} & \mathrm{Y}\end{array}$

121 ACCTTCGCCTTCCAGGCTGAGATCAACCAGCTGCTCAGTCTGATCATTAACACGTTCTAC

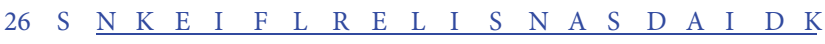

Signature motif-1

181 TCCAACAAGGAAATCTTCTTGAGGGAACTGATCAGCAATGCCTCGGACGCTATTGACAAA

$\begin{array}{lllllllllllllllllllll}46 & \mathrm{~V} & \mathrm{R} & \mathrm{F} & \mathrm{Q} & \mathrm{S} & \mathrm{L} & \mathrm{T} & \mathrm{D} & \mathrm{K} & \mathrm{S} & \mathrm{V} & \mathrm{L} & \mathrm{E} & \mathrm{S} & \mathrm{N} & \mathrm{P} & \mathrm{E} & \mathrm{L} & \mathrm{Y} & \mathrm{I}\end{array}$

241 GTCCGTTTCCAGTCCCTCACTGACAAGTCGGTGCTGGAGAGCAACCCAGAGCTTTACATC

$\begin{array}{lllllllllllllllllllll}66 & \mathrm{H} & \mathrm{I} & \mathrm{T} & \mathrm{P} & \mathrm{D} & \mathrm{K} & \mathrm{A} & \mathrm{N} & \mathrm{N} & \mathrm{T} & \mathrm{L} & \mathrm{T} & \mathrm{I} & \mathrm{T} & \mathrm{D} & \mathrm{S} & \mathrm{G} & \mathrm{V} & \mathrm{G} & \mathrm{M}\end{array}$

301 CACATCACGCCTGACAAGGCCAACAACACGCTCACGATCACAGACTCTGGTGTCGGCATG

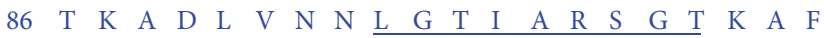

Signature motif-2

361 ACAAAGGCGGATCTGGTGAACAACTTGGGAACCATCGCACGCTCGGGGACCAAGGCGTTC

106 M E A L S A G A D I S M I G Q F G V G F

Signature motif-3

421 ATGGAGGCTCTGAGTGCCGGCGCGGACATCAGCATGATTGGCCAGTTCGGCGTGGGTTTC

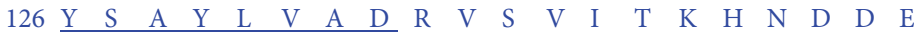

481 TACTCCGCCTACCTGGTTGCAGACCGCGTGAGCGTCATCACAAAGCACAACGATGACGAG

$\begin{array}{lllllllllllllllllllll}146 & \text { Q } & Y & \text { I } & \text { W } & \text { E } & S & Q & \text { A } & G & G & S & F & T & I & A & R & D & T & V & N\end{array}$

541 CAGTACATATGGGAGAGCCAGGCCGGCGGCTCTTTCACCATCGCGCGTGACACCGTCAAC

$\begin{array}{lllllllllllllllllllll}166 & \mathrm{P} & \mathrm{S} & \mathrm{L} & \mathrm{G} & \mathrm{R} & \mathrm{G} & \mathrm{T} & \mathrm{Q} & \mathrm{I} & \mathrm{T} & \mathrm{L} & \mathrm{H} & \mathrm{L} & \mathrm{K} & \mathrm{E} & \mathrm{D} & \mathrm{Q} & \mathrm{M} & \mathrm{E} & \mathrm{Y}\end{array}$

601 CCGTCGCTTGGCCGCGGCACGCAGATCACCCTCCACCTCAAGGAGGACCAGATGGAGTAC

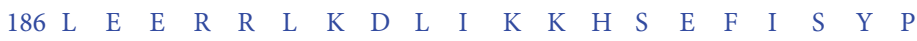

661 CTCGAGGAGCGCCGCCTCAAGGACTTGATCAAGAAGCACAGCGAGTTCATCTCGTACCCG

$\begin{array}{lllllllllllllllllllllllllll}206 & \mathrm{I} & \mathrm{S} & \mathrm{L} & \mathrm{W} & \mathrm{V} & \mathrm{E} & \mathrm{K} & \mathrm{T} & \mathrm{T} & \mathrm{E} & \mathrm{K} & \mathrm{E} & \mathrm{V} & \mathrm{D} & \mathrm{D} & \mathrm{D} & \mathrm{E} & \mathrm{E} & \mathrm{E} & \mathrm{E}\end{array}$

721 ATCAGCCTGTGGGTGGAGAAGACCACCGAGAAGGAGGTGGATGATGACGAGGAGGAGGAG

$\begin{array}{lllllllllllllllllllll}26 & \mathrm{P} & \mathrm{K} & \mathrm{D} & \mathrm{D} & \mathrm{D} & \mathrm{E} & \mathrm{E} & \mathrm{G} & \mathrm{K} & \mathrm{V} & \mathrm{E} & \mathrm{E} & \mathrm{I} & \mathrm{K} & \mathrm{E} & \mathrm{E} & \mathrm{E} & \mathrm{E} & \mathrm{E} & \mathrm{E}\end{array}$

781 CCCAAGGACGACGACGAGGAGGGCAAGGTTGAGGAGATCAAGGAGGAGGAGGAGGAGGAG

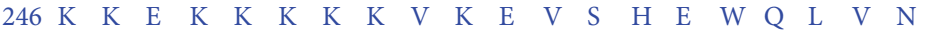

841 AAGAAGGAGAAGAAGAAGAAGAAGGTGAAGGAGGTGTCGCACGAGTGGCAGCTGGTGAAC

$\begin{array}{lllllllllllllllllllll}266 & \mathrm{~K} & \mathrm{Q} & \mathrm{K} & \mathrm{P} & \mathrm{I} & \mathrm{W} & \mathrm{M} & \mathrm{R} & \mathrm{N} & \mathrm{P} & \mathrm{E} & \mathrm{E} & \mathrm{I} & \mathrm{S} & \mathrm{K} & \mathrm{E} & \mathrm{E} & \mathrm{Y} & \mathrm{E} & \mathrm{A}\end{array}$

901 AAGCAGAAGCCCATCTGGATGCGCAACCCCGAGGAGATCTCCAAGGAGGAGTACGAGGCC

$\begin{array}{llllllllllllllllllllll}286 & \mathrm{~F} & \mathrm{Y} & \mathrm{K} & \mathrm{S} & \mathrm{L} & \mathrm{T} & \mathrm{N} & \mathrm{D} & \mathrm{W} & \mathrm{E} & \mathrm{E} & \mathrm{P} & \mathrm{L} & \mathrm{A} & \mathrm{Q} & \mathrm{K} & \mathrm{H} & \mathrm{F} & \mathrm{A} & \mathrm{V}\end{array}$

961 TTCTACAAGTCCCTCACCAATGACTGGGAGGAGCCCCTGGCGCAGAAGCACTTTGCTGTG

$\begin{array}{llllllllllllllllllllll}306 & \mathrm{E} & \mathrm{G} & \mathrm{Q} & \mathrm{L} & \mathrm{E} & \mathrm{F} & \mathrm{K} & \mathrm{S} & \mathrm{I} & \mathrm{L} & \mathrm{F} & \mathrm{V} & \mathrm{P} & \mathrm{K} & \mathrm{R} & \mathrm{A} & \mathrm{P} & \mathrm{F} & \mathrm{D} & \mathrm{L}\end{array}$

1021 GAGGGCCAGCTAGAGTTCAAGTCCATCCTCTTCGTGCCCAAGCGCGCCCCCTTCGACCTC

$\begin{array}{llllllllllllllllllllll}326 & F & D & T & R & K & K & S & N & N & I & K & L & Y & V & R & R & V & F & I & M\end{array}$

Signature motif-4

1081 TTCGACACCAGGAAGAAGTCGAACAACATCAAGCTGTATGTGAGGCGGGTGTTCATCATG

\begin{tabular}{lllllllllllllllllllll}
346 & $\mathrm{D}$ & $\mathrm{N}$ & $\mathrm{C}$ & $\mathrm{E}$ & $\mathrm{E}$ & $\mathrm{L}$ & $\mathrm{I}$ & $\mathrm{P}$ & $\mathrm{E}$ & $\mathrm{W}$ & $\mathrm{L}$ & $\mathrm{G}$ & $\mathrm{F}$ & $\mathrm{M}$ & $\mathrm{K}$ & $\mathrm{G}$ & $\mathrm{I}$ & $\mathrm{V}$ & $\mathrm{D}$ & $\mathrm{S}$ \\
\hline
\end{tabular}

1141 GACAACTGCGAGGAGCTCATCCCCGAGTGGCTCGGCTTCATGAAGGGCATCGTGGACAGC

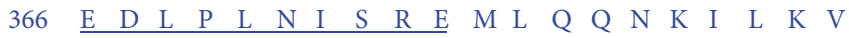

Signature motif-5

1201 GAGGACCTGCCCCTCAACATCTCCCGCGAGATGCTCCAGCAGAACAAGATCCTCAAGGTC

$\begin{array}{lllllllllllllllllllll}386 & \text { I } & K & K & N & L & I & K & K & S & I & E & L & F & N & E & I & A & E & N & K\end{array}$

1261 ATCAAGAAGAACCTCATCAAGAAGAGCATTGAGCTCTTCAATGAGATTGCCGAGAACAAG

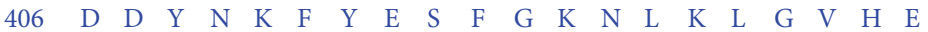

1321 GATGACTACAACAAGTTCTACGAGTCCTTCGGCAAGAACCTGAAGCTGGGAGTGCACGAG

$\begin{array}{llllllllllllllllllllll}426 & \mathrm{D} & \mathrm{S} & \mathrm{A} & \mathrm{N} & \mathrm{R} & \mathrm{S} & \mathrm{K} & \mathrm{L} & \mathrm{A} & \mathrm{E} & \mathrm{L} & \mathrm{L} & \mathrm{R} & \mathrm{Y} & \mathrm{H} & \mathrm{S} & \mathrm{T} & \mathrm{K} & \mathrm{S} & \mathrm{G}\end{array}$

1381 GACAGCGCCAACCGCTCCAAGCTGGCAGAGCTGCTCCGCTACCACTCCACCAAGTCTGGT

$\begin{array}{lllllllllllllllllllll}46 & \mathrm{E} & \mathrm{E} & \mathrm{L} & \mathrm{T} & \mathrm{S} & \mathrm{L} & \mathrm{K} & \mathrm{D} & \mathrm{Y} & \mathrm{V} & \mathrm{T} & \mathrm{R} & \mathrm{M} & \mathrm{K} & \mathrm{E} & \mathrm{S} & \mathrm{Q} & \mathrm{K} & \mathrm{D} & \mathrm{I}\end{array}$

1441 GAGGAGCTGACGAGTCTGAAGGACTATGTGACCCGGATGAAGGAGAGCCAGAAGGACATC

$\begin{array}{llllllllllllllllllllllllll}466 & Y & Y & I & T & G & E & S & R & K & A & V & E & N & S & P & F & I & E & R & L\end{array}$

1501 TACTACATCACCGGCGAGTCGCGCAAGGCCGTCGAGAACTCCCCCTTCATCGAGCGCCTC

$\begin{array}{lllllllllllllllllllll}486 & \mathrm{~K} & \mathrm{~K} & \mathrm{~K} & \mathrm{~N} & \mathrm{~L} & \mathrm{E} & \mathrm{V} & \mathrm{L} & \mathrm{F} & \mathrm{L} & \mathrm{V} & \mathrm{D} & \mathrm{P} & \mathrm{I} & \mathrm{D} & \mathrm{E} & \mathrm{Y} & \mathrm{A} & \mathrm{V} & \mathrm{Q}\end{array}$

1561 AAGAAGAAGAACCTCGAGGTGCTGTTCCTGGTGGACCCCATCGATGAGTATGCGGTGCAG

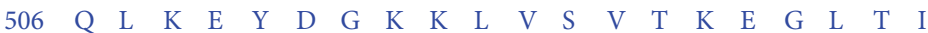
1621 CAGCTGAAGGAGTACGACGGCAAGAAGCTGGTGAGCGTGACCAAGGAGGGCCTGACTATC $\begin{array}{lllllllllllllllllllll}526 & \mathrm{D} & \mathrm{E} & \mathrm{T} & \mathrm{E} & \mathrm{E} & \mathrm{D} & \mathrm{K} & \mathrm{K} & \mathrm{R} & \mathrm{L} & \mathrm{E} & \mathrm{E} & \mathrm{L} & \mathrm{K} & \mathrm{A} & \mathrm{S} & \mathrm{Y} & \mathrm{E} & \mathrm{P} & \mathrm{L}\end{array}$ 1681 GACGAGACCGAGGAGGACAAAAAGCGGCTGGAGGAGCTCAAGGCCTCCTACGAGCCCCTC $\begin{array}{llllllllllllllllllllll}546 & \mathrm{C} & \mathrm{G} & \mathrm{L} & \mathrm{I} & \mathrm{K} & \mathrm{D} & \mathrm{I} & \mathrm{L} & \mathrm{S} & \mathrm{D} & \mathrm{K} & \mathrm{V} & \mathrm{E} & \mathrm{K} & \mathrm{V} & \mathrm{V} & \mathrm{V} & \mathrm{G} & \mathrm{E} & \mathrm{R}\end{array}$

(a)

Figure 1: Continued. 


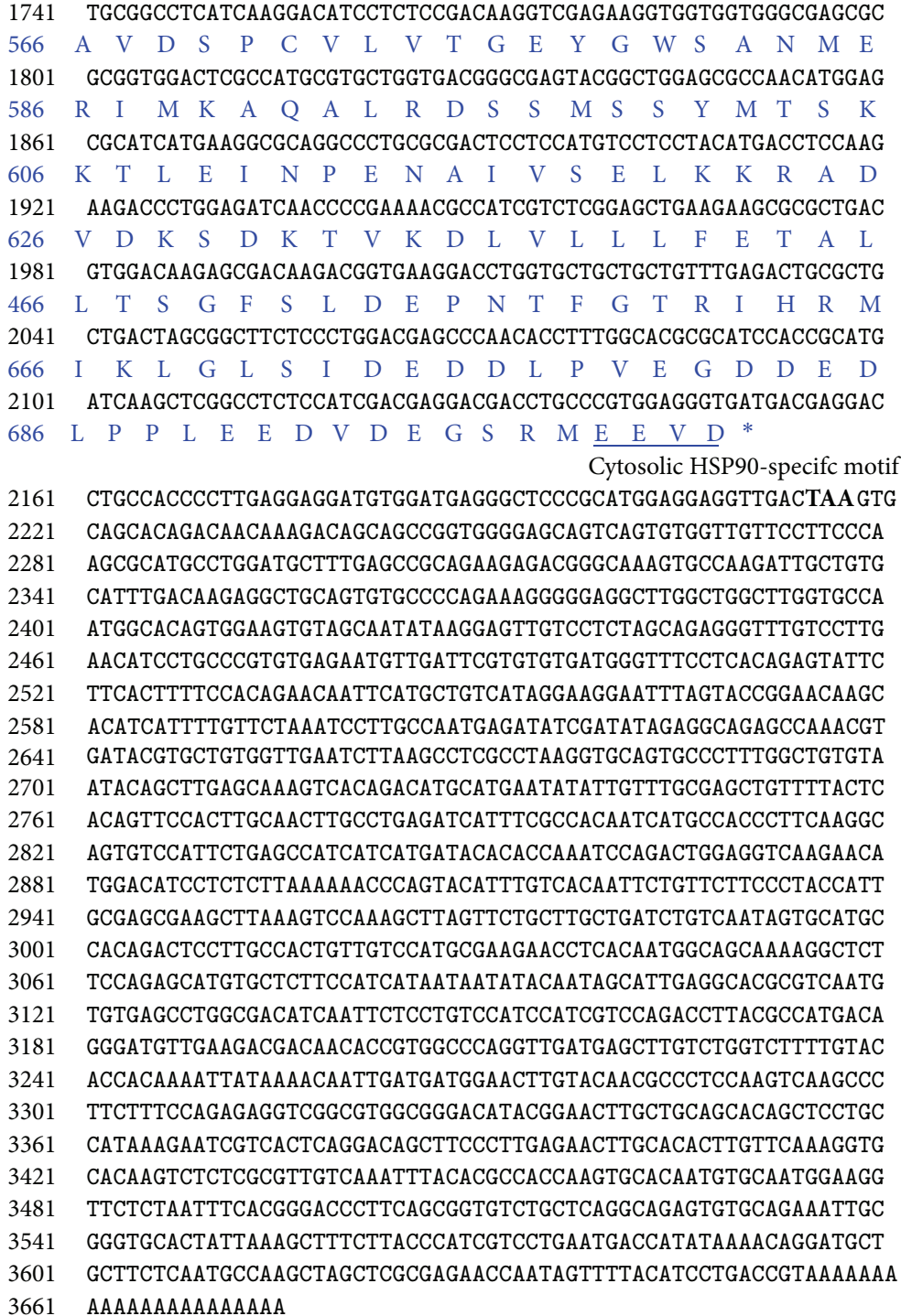

(b)

FIGURE 1: The full length cDNA sequence of CvHSP90 and its deduced amino acid sequence. The nucleotide and deduced amino acid sequence of the open reading frame and flanking region were numbered on the left. The start and stop codons were bold. HSP 90 signature motifs and cytosolic HSP90-specific motif were underlined.

3.4. Expression Levels of CvHSP90 under Different Heat Shock Temperatures. The expression level of CvHSP90 was investigated by real-time quantitative PCR under different stressful conditions. As the optimal growth temperature for C. vulgaris is $20-25^{\circ} \mathrm{C}$, different heat shock temperatures (5$45^{\circ} \mathrm{C}$ ) was scheduled to study the mRNA expression levels of CvHSP90 (Figure 4). In $20^{\circ} \mathrm{C}$ and $25^{\circ} \mathrm{C}$ treatment groups, the expression levels of CvHSP90 were relatively low, while in $5^{\circ} \mathrm{C}$ and $35^{\circ} \mathrm{C}$ treatment groups were almost 2.5 -fold of that in $20^{\circ} \mathrm{C}$ group $(P<0.05)$. The highest expression level (3-fold of that in $20^{\circ} \mathrm{C}$ group) was determined at $40^{\circ} \mathrm{C}$ for $1 \mathrm{~h}(P<0.01)$.

3.5. Expression Levels of CvHSP90 at Different Heat Shock Times. In this study, we found that a long time (over $8 \mathrm{~h}$ ) exposure at over $40^{\circ} \mathrm{C}$ would be fatal to C. vulgaris. Therefore, the organism was kept at $35^{\circ} \mathrm{C}$ for different hours to find the impact of different heat shock times on the expression level of CvHSP90. As shown in Figure 5, in $35^{\circ} \mathrm{C}$, CvHSP90 mRNA expression level increased gradually and reached the maximum (4.2-fold of that of blank group) at $7 \mathrm{~h}(P<0.01)$ and then declined progressively to the original level at $12 \mathrm{~h}$. Under a heat shock, the expression level of CvHSP90 was observed significantly different at $1,2,3,4,5,8$, and $9 \mathrm{~h}$ from that of the blank group $(P<0.05)$.

3.6. Expression Levels of CvHSP90 under Different Salt Concentrations. The expression levels of CvHSP90 at different salt concentrations for $2 \mathrm{~h}$ were detected (Figure 6). The expression level of CvHSP90 at 10, 15, 20, and 30 in salinity 

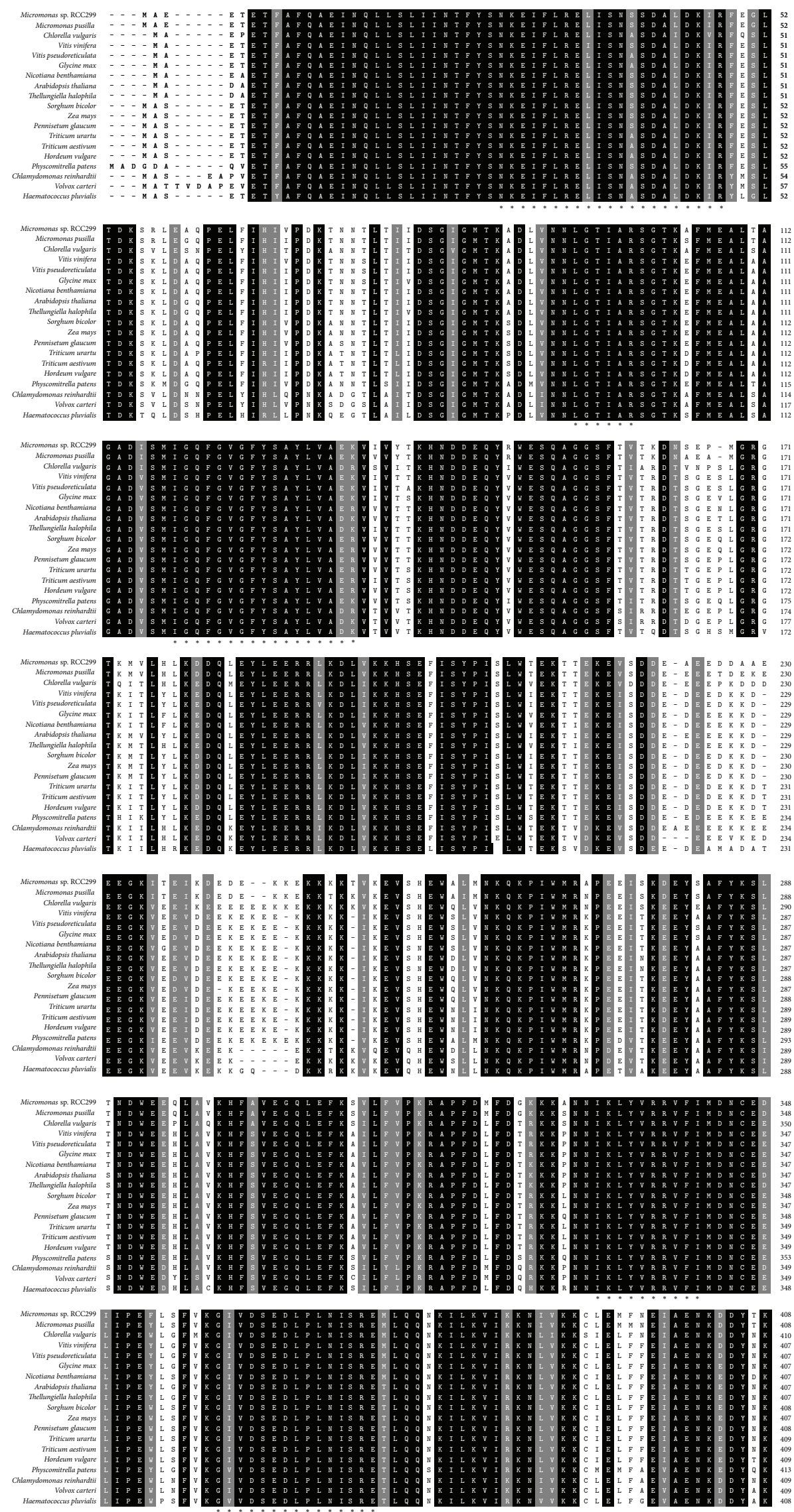

(a)

Figure 2: Continued. 


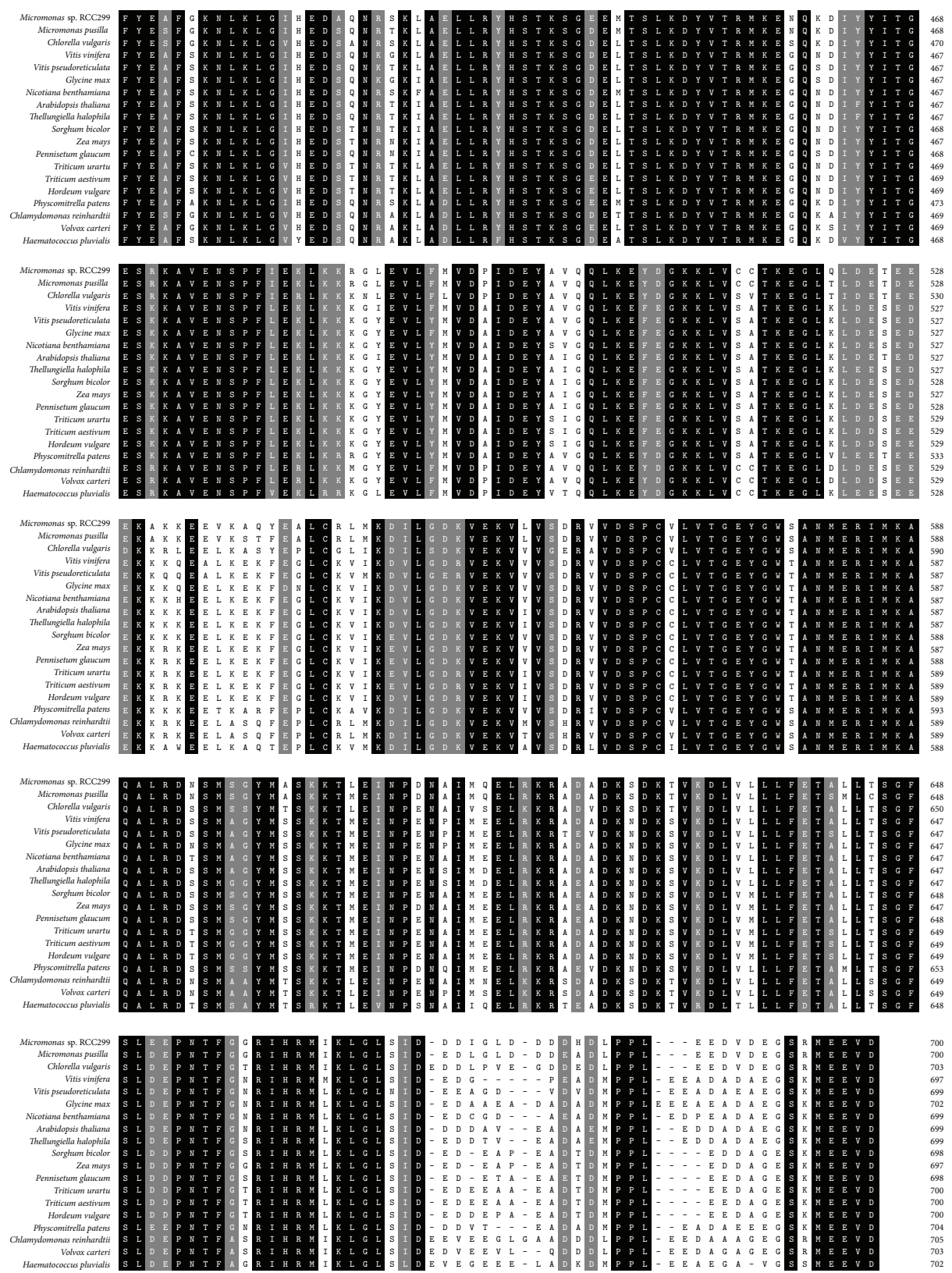

(b)

FIGURE 2: Multiple sequence alignment of the CvHSP90 with other registered counterparts from Haematococcus pluvialis (JN627245), Chlamydomonas reinhardtii (XP_001695264), Volvox carteri f. nagariensis (XP_002947115), Micromonas sp. RCC299 (XP_002499727), Pennisetum glaucum (ADP89125), Hordeum vulgare (BAJ86355), Triticum aestivum (ADF31758), Triticum urartu (ADF31773), Vitis vinifera (CAN62488), Thellungiella halophila (BAJ33984), Micromonas pusilla CCMP1545 (XP_003058104), Physcomitrella patens (XP_001777414), Sorghum bicolor (XP_002444804), Arabidopsis thaliana (AAN31859), Vitis pseudoreticulata (ABW96308), Nicotiana benthamiana (AAR12194), Glycine max (ADC45395), and Zea mays (NP_001170475). The black shaded regions represent identical amino acids among the different species, while the gray shaded regions represent conservative replacements. The HSP90 signature motifs and cytosolic HSP90specific motif were indicated with asterisks.

(\%o) for $2 \mathrm{~h}$ showed no significant difference from that at 25 in salinity. However, the expression level at salinity over 25 increased significantly $(P<0.05)$. The expression levels at 40 or 45 salinity were almost 4 -fold of that at 25 salinity for $2 \mathrm{~h}(P<0.01)$. The results show that $C$. vulgaris responded strongly to high salinity stress.

\section{Discussion}

HSP90, as an important member of HSPs, centrally functions in various biological processes in the presence and absence of stresses, including biogenesis, folding, transport, degradation, and prevention of misfolding and aggregation of cellular 
TABLE 2: Sequences used for multiple alignment and phylogenetic analysis.

\begin{tabular}{|c|c|c|c|}
\hline Species & Taxonomy & Accession & Similarity\% \\
\hline Arabidopsis thaliana & Streptophyta; Magnoliophyta; Eudicotyledons & AAN31859 & $77 \%$ \\
\hline Chlamydomonas reinhardtii & Chlorophyta; Chlorophyceae & XP_001695264 & $79 \%$ \\
\hline Chlorella vulgaris & Chlorophyta; Trebouxiophyceae & JQ655149 & $100 \%$ \\
\hline Glycine max & Streptophyta; Magnoliophyta; Eudicotyledons & ADC45395 & $77 \%$ \\
\hline Haematococcus pluvialis & Chlorophyta; Chlorophyceae & JN627245 & $79 \%$ \\
\hline Hordeum vulgare subsp. vulgare & Streptophyta; Magnoliophyta; Liliopsida & BAJ86355 & $78 \%$ \\
\hline Micromonas pusilla CCMP1545 & Chlorophyta; Mamiellophyceae & XP_003058104 & $85 \%$ \\
\hline Micromonas sp. RCC299 & Chlorophyta; Mamiellophyceae & XP_002499727 & $85 \%$ \\
\hline Nicotiana benthamiana & Streptophyta; Magnoliophyta; Eudicotyledons & AAR12194 & $77 \%$ \\
\hline Pennisetum glaucum & Streptophyta; Magnoliophyta; Liliopsida & ADP89125 & $78 \%$ \\
\hline Physcomitrella patens subsp. patens & Streptophyta; Bryophyta; & XP_001777414 & $77 \%$ \\
\hline Sorghum bicolor & Streptophyta; Magnoliophyta; Liliopsida & XP_002444804 & $77 \%$ \\
\hline Thellungiella halophila & Streptophyta; Magnoliophyta; Eudicotyledons & BAJ33984 & $78 \%$ \\
\hline Triticum aestivum & Streptophyta; Magnoliophyta; Liliopsida & ADF31758 & $78 \%$ \\
\hline Triticum urartu & Streptophyta; Magnoliophyta; Liliopsida & ADF31773 & $78 \%$ \\
\hline Vitis pseudoreticulata & Streptophyta; Magnoliophyta; Eudicotyledons & ABW96308 & $77 \%$ \\
\hline Vitis vinifera & Streptophyta; Magnoliophyta; Eudicotyledons & CAN62488 & $78 \%$ \\
\hline Volvox carteri $\mathrm{f}$. nagariensis & Chlorophyta; Chlorophyceae & XP_002947115 & $79 \%$ \\
\hline Zea mays & Streptophyta; Magnoliophyta; Liliopsida & NP_001170475 & $76 \%$ \\
\hline
\end{tabular}

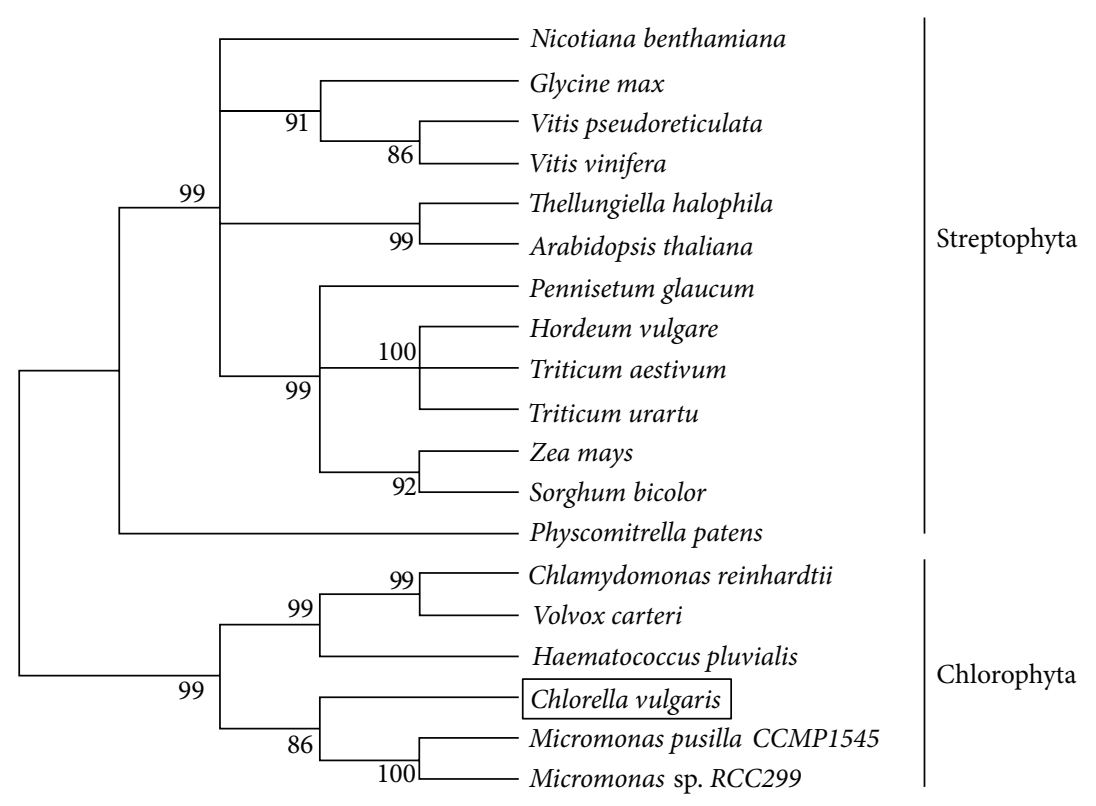

FIGURE 3: A phylogenetic tree constructed with the neighbor-joining method. The common names and the GenBank accession numbers were the same as those in Figure 2. Numbers at each branch indicate the percentage of times a node was supported in 1000 bootstrap pseudoreplication by neighbor joining.

proteins and signal transduction $[2,9,35]$. In macroalgae, the expression of the HSP genes has been investigated in several genus as they usually live in intertidal zone which characterized by regular and extreme changes in abiotic conditions, based on tidal influence [14]. However, the studies of HSP90 in algae are relatively limited [21, 27]. Chlorella vulgaris, as an important economical species, is also an important model species in studies on stress responses [30]. Therefore, the role of Chlorella vulgaris HSP90 (designated CvHSP90) in response to adverse environment was investigated in this work.

In photosynthetic eukaryotes, Hsp90 family proteins are divided into five types with localization in different cellular compartments including nucleoplasm, chloroplasts, mitochondria, ER, and cytoplasm [6]. Sequence analysis of the deduced AA sequence showed that CvHSP90 contains 


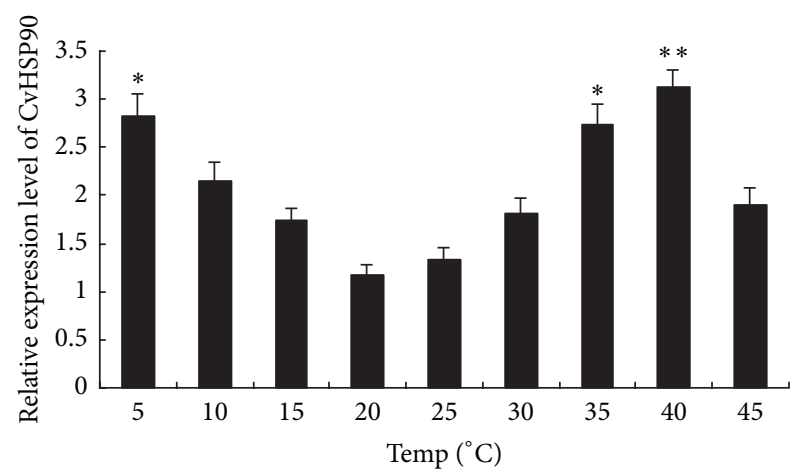

Figure 4: CvHSP90 mRNA expression levels under different heat shock temperatures $\left(5^{\circ} \mathrm{C}, 10^{\circ} \mathrm{C}, 15^{\circ} \mathrm{C}, 20^{\circ} \mathrm{C}, 25^{\circ} \mathrm{C}, 30^{\circ} \mathrm{C}, 35^{\circ} \mathrm{C}, 40^{\circ} \mathrm{C}\right.$, and $45^{\circ} \mathrm{C}$ ) for $1 \mathrm{~h}$ were analyzed by real-time quantitative reverse transcriptase-polymerase chain reaction. The $\beta$-actin gene was used as an internal control to calibrate the cDNA template for all the samples. Vertical bars represented the mean $\pm \mathrm{SE}(N=5)$.

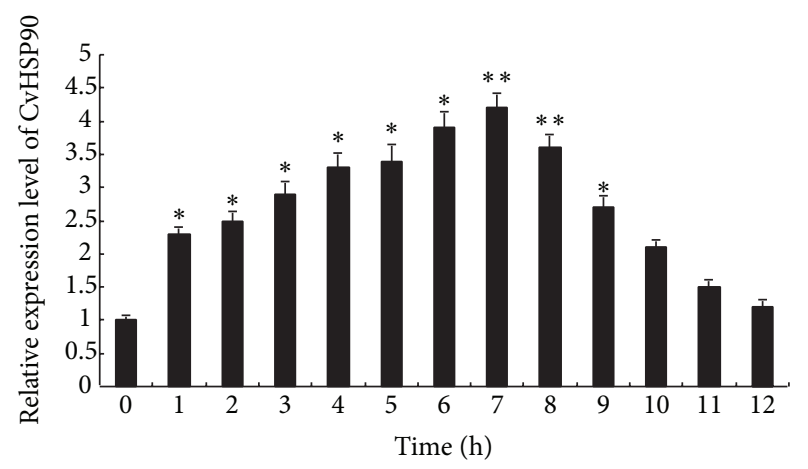

FIgURE 5: CvHSP90 mRNA expression levels in different heat shock times ( 0 h, $1 \mathrm{~h}, 2 \mathrm{~h}, 3 \mathrm{~h}, 4 \mathrm{~h}, 5 \mathrm{~h}, 6 \mathrm{~h}, 7 \mathrm{~h}, 8 \mathrm{~h}, 9 \mathrm{~h}, 10 \mathrm{~h}, 11 \mathrm{~h}$, and $12 \mathrm{~h}$ ) at $35^{\circ} \mathrm{C}$ were analyzed by real-time quantitative RT-PCR. CvHSP90 mRNA expression was normalized to the control group, and $\beta$-actin gene was used as internal control to calibrate the cDNA template for all the samples. Each bar represents the mean value from five determinations with standard error. Significant differences across control were indicated with an asterisk at $P<0.05$ and two asterisks at $P<0.01$.

the five typical signature motifs of the HSPs $[10,11,36]$. Moreover, the MEEVD motif which is cytoplasmic Hsp90specific is identified at the C-terminus. The MEEVD motif participates in the formation of a Hsp90/Hop/Hsp70 protein complex concerning the assembly of steroid hormone receptors by associating with cytoplasmic Hsp70 through a Hsporganizing protein (Hop). In addition, multiple alignment and phylogenetic analysis showed high similarities among the deduced amino acid sequence of CvHSP90 and other known HSP90s (more than 75\% similarity in all the matches), especially with those from Mamiellophyceae Micromonas sp. RCC299 and Micromonas pusilla CCMP1545 (85\% similarity in each match). In terms of sequence alignment, structure comparison, and phylogenetic analysis, CvHSP90 was confirmed to be a cytoplasmic Hsp90.

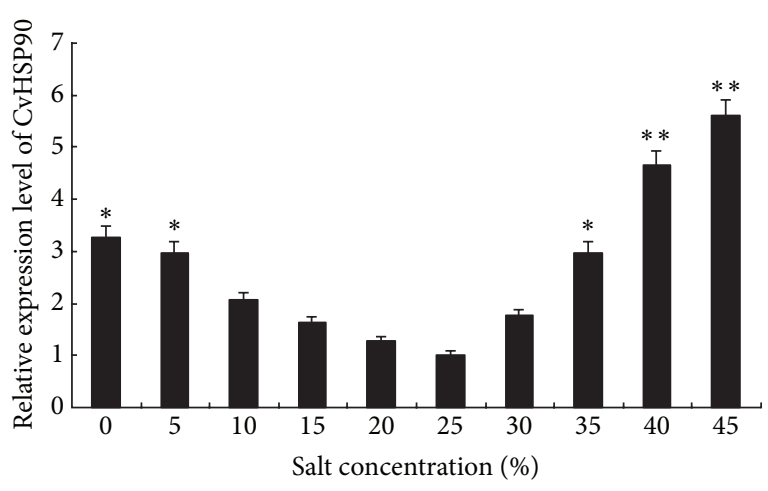

Figure 6: CvHSP90 mRNA expression levels relative to $\beta$-actin mRNA levels under stress of different salt concentrations analyzed by real-time quantitative RT-PCR. The $\beta$-actin gene was used as an internal control to calibrate the cDNA template for all the samples. Vertical bars represented the mean \pm SE $(N=5)$. Significant differences across control were indicated with an asterisk at $P<0.05$ and two asterisks at $P<0.01$.

It is a main character for almost all organisms studied that the maximum expression of HSPs is $10-15^{\circ} \mathrm{C}$ above optimum growth temperature [18]. Moreover, it has been proved that the temperature treatment in the range $10-15^{\circ} \mathrm{C}$ below optimum growth temperature may also lead to the maximum expression of HSP90 [27]. Given that the normal growing temperature range of C. vulgaris is $20-25^{\circ} \mathrm{C}$, in which the expression level of HSP90s is always low, it can be expected that the maximum CvHSP90 expression would be in the ranges of $35-40^{\circ} \mathrm{C}$ and $5-10^{\circ} \mathrm{C}$, which was consistent with our results. In macroalgae, short time treatment in temperature higher than normal growth temperature can induce the expression of HSPs, which is upregulated by increased thermal stresses and then decreased progressively after the expression profile reached the maximum [37]. In this work, we observed that $45^{\circ} \mathrm{C}$ treatment which is $15^{\circ} \mathrm{C}$ over the optimum temperature led to the decrease of CvHSP90 expression, which may be caused by immediate deactivation or strong inhibition of enzyme-related mRNA synthesis and expression in C. vulgaris [19]. Furthermore, the timedependent pattern of CvHSP90 expression in a heat shock was observed. In heat shock at $35^{\circ} \mathrm{C}$, the expression increased progressively in $1 \mathrm{~h}$ and reached the maximum in $7 \mathrm{~h}$ and then declined gradually. Variance analysis indicated that the CvHSP90 gene expression in 6 or 7 hours after challenge was significantly higher $(P<0.01)$ than those in other time points. These results suggested that the CvHSP90 expression is related to the response to thermal stress and heat shock time and may play an important role in the mechanism against the adverse environmental stresses. In natural environment, C. vulgaris usually grows in salinity $20-30 \%$. Its utilization in wastewater treatment suggests that it is highly resistant to a range of salinity. In this work, the result showed that the mRNA expression levels of CvHSP90 varied with salinity and suggested its function in resistance to salinity stress. In addition, the CvHSP90 expression at different times under a fixed level of salinity stress needs to be further studied. 


\section{Conclusions}

The CvHSP90 gene can be expressed in response to challenges in thermal stress, heat shock time, and salinity. In a stressful environment, changes in HSP90s expression level are more sensitive than those of growth rate, death rate, and reproductive rate for monitoring environmental stresses. Therefore, CvHSP90 can be used as a potential biomarker in practice to monitor environment changes.

\section{Conflict of Interests}

The authors declare that there is no conflict of interests regarding the publication of this paper.

\section{Acknowledgment}

This work was supported by the National Key Technology R\&D Program of China (Grant no. 2013BAB01B01).

\section{References}

[1] F. Ritossa, "A new puffing pattern induced by temperature shock and DNP in drosophila," Experientia, vol. 18, no. 12, pp. 571-573, 1962.

[2] C. Prassinos, K. Haralampidis, D. Milioni, D. Samakovli, K. Krambis, and P. Hatzopoulos, "Complexity of Hsp90 in organelle targeting," Plant Molecular Biology, vol. 67, no. 4, pp. 323-334, 2008.

[3] J. G. Sørensen, T. N. Kristensen, and V. Loeschcke, "The evolutionary and ecological role of heat shock proteins," Ecology Letters, vol. 6, no. 11, pp. 1025-1037, 2003.

[4] P. Csermely, T. Schnaider, C. Soti, Z. Prohászka, and G. Nardai, "The 90-kDa molecular chaperone family: structure, function, and clinical applications. A comprehensive review," Pharmacology and Therapeutics, vol. 79, no. 2, pp. 129-168, 1998.

[5] F. U. Hartl, A. Bracher, and M. Hayer, "Molecular chaperones in protein folding and proteostasis," Nature, vol. 475, no. 7356, pp. 324-332, 2011.

[6] H. Hao, Y. Naomoto, X. Bao et al., "HSP90 and its inhibitors," Oncology Reports, vol. 23, no. 6, pp. 1483-1492, 2010.

[7] G. Schatz and B. Dobberstein, "Common principles of protein translocation across membranes," Science, vol. 271, no. 5255, pp. 1519-1526, 1996.

[8] S. L. Rutherford and S. Lindquist, "Hsp90 as a capacitor for morphological evolution," Nature, vol. 396, no. 6709, pp. 336342, 1998.

[9] J. C. Young, I. Moarefi, and F. Ulrich Hartl, "Hsp90: a specialized but essential protein-folding tool," Journal of Cell Biology, vol. 154, no. 2, pp. 267-273, 2001.

[10] D. Milioni and P. Hatzopoulos, "Genomic organization of hsp90 gene family in Arabidopsis," Plant Molecular Biology, vol. 35, no. 6, pp. 955-961, 1997.

[11] D. Cao, J. E. Froehlich, H. Zhang, and C. L. Cheng, "The chlorate-resistant and photomorphogenesis-defective mutant cr88 encodes a chloroplast-targeted HSP90," Plant Journal, vol. 33, no. 1, pp. 107-118, 2003.

[12] D. Liu, X. Zhang, Y. Cheng, T. Takano, and S. Liu, "rHsp90 gene is in response to several environmental stresses in rice (Oryza sativa L.)," Plant Physiology and Biochemistry, vol. 44, no. 5-6, pp. 380-386, 2006.
[13] X. Xu, H. Song, Z. Zhou, N. Shi, Q. Ying, and H. Wang, "Functional characterization of AtHsp90.3 in Saccharomyces cerevisiae and Arabidopsis thaliana under heat stress," Biotechnology Letters, vol. 32, no. 7, pp. 979-987, 2010.

[14] I. R. Davison and G. A. Pearson, "Stress tolerance in intertidal seaweeds," Journal of Phycology, vol. 32, no. 2, pp. 197-211, 1996.

[15] J. Collén, I. G. Marsollier, J. J. Léger, and C. Boyen, "Response of the transcriptome of the intertidal red seaweed Chondrus crispus to controlled and natural stresses," New Phytologist, vol. 176, no. 1, pp. 45-55, 2007.

[16] G. A. Pearson, G. Hoarau, A. Lago-Leston et al., "An expressed sequence tag analysis of the intertidal brown seaweeds Fucus serratus (L.) and F. vesiculosus (L.) (Heterokontophyta, Phaeophyceae) in response to abiotic stressors," Marine Biotechnology, vol. 12, no. 2, pp. 195-213, 2010.

[17] W. Fu, J. Yao, X. Wang, F. Liu, G. Fu, and D. Duan, "Molecular cloning and expression analysis of a cytosolic Hsp70 gene from Laminaria japonica (Laminariaceae, Phaeophyta)," Marine Biotechnology, vol. 11, no. 6, pp. 738-747, 2009.

[18] W. D. Fu, Molecular cloning and expression analysis of cytosolic HSP70 genes from four kinds of seaweeds [Ph.D. thesis], 2009.

[19] W. D. Fu, L. Shuai, J. Yao, B. Zheng, M. Zhong, and D. Duan, "Molecular cloning and expression analysis of a cytosolic Hsp70 gene from Ulva pertusa (Ulvophyceae, Chlorophyta)," Journal of Applied Phycology, vol. 23, no. 4, pp. 681-690, 2011.

[20] H. S. Park, W. J. Jeong, E. Kim et al., "Heat shock protein gene family of the Porphyra seriata and enhancement of heat stress tolerance by PsHSP70 in Chlamydomonas," Marine Biotechnology, vol. 14, no. 3, pp. 332-342, 2012.

[21] H. Tominaga, D. A. Coury, H. Amano, W. Miki, and M. Kakinuma, "CDNA cloning and expression analysis of two heat shock protein genes, Hsp90 and Hsp60, from a sterile Ulva pertusa (Ulvales, Chlorophyta)," Fisheries Science, vol. 78, no. 2, pp. 415-429, 2012.

[22] S. Heinrich, K. Valentin, S. Frickenhaus et al., "Transcriptomic analysis of acclimation to temperature and light stress in Saccharina latissima (Phaeophyceae)," PLOS ONE, vol. 7, no. 8, pp. 1-13, 2012.

[23] M. Schroda, "The Chlamydomonas genome reveals its secrets: chaperone genes and the potential roles of their gene products in the chloroplast," Photosynthesis Research, vol. 82, no. 3, pp. 221-240, 2004.

[24] F. Willmund, K. V. Dorn, M. Schulz-Raffelt, and M. Schroda, "The chloroplast DnaJ homolog CDJ1 of Chlamydomonas reinhardtii is part of a multichaperone complex containing HSP70B, CGE1, and HSP90C," Plant Physiology, vol. 148, no. 4, pp. 20702082, 2008.

[25] E. Spijkerman, D. Barua, A. Gerloff-Elias, J. Kern, U. Gaedke, and S. A. Heckathorn, "Stress responses and metal tolerance of Chlamydomonas acidophila in metal-enriched lake water and artificial medium," Extremophiles, vol. 11, no. 4, pp. 551-562, 2007.

[26] F. Willmund and M. Schroda, "Heat shock protein 90C is a bona fide Hsp90 that interacts with plastidic HSP70B in Chlamydomonas reinhardtii," Plant Physiology, vol. 138, no. 4, pp. 2310-2322, 2005.

[27] L. Zhang, Y. Fan, F. Shi, S. Qin, and B. Liu, "Molecular cloning, characterization, and expression analysis of a cytosolic HSP90 gene from Haematococcus pluvialis," Journal of Applied Phycology, pp. 1-12, 2012.

[28] V. Blas-Valdivia, R. Ortiz-Butrón, M. Pineda-Reynoso, A. Hernández-Garcia, and E. Cano-Europa, "Chlorella vulgaris 
administration prevents $\mathrm{HgCl}_{2}$-caused oxidative stress and cellular damage in the kidney," Journal of Applied Phycology, vol. 23, no. 1, pp. 53-58, 2011.

[29] Y. F. Niu, M. H. Zhang, W. H. Xie et al., "A new inducible expression system in a transformed green alga, Chlorella vulgaris," Genetics and Molecular Research, vol. 10, no. 4, pp. 3427-3434, 2011.

[30] Y. L. Wang and X. D. Xu, "Construction of cosmid libraries of the Antarctic and temperate strains of Chlorella vulgaris," Acta Hydrobiologica Sinica, vol. 35, no. 6, pp. 1063-1066, 2011.

[31] S. Kumar, K. Tamura, and M. Nei, "MEGA3: integrated software for molecular evolutionary genetics analysis and sequence alignment," Briefings in Bioinformatics, vol. 5, no. 2, pp. 150-163, 2004.

[32] J. D. Thompson, T. J. Gibson, F. Plewniak, F. Jeanmougin, and D. G. Higgins, "The CLUSTAL X windows interface: flexible strategies for multiple sequence alignment aided by quality analysis tools," Nucleic Acids Research, vol. 25, no. 24, pp. 48764882, 1997.

[33] K. J. Livak and T. D. Schmittgen, "Analysis of relative gene expression data using real-time quantitative PCR and the 2(Delta Delta C(T)) Method," Methods, vol. 25, no. 4, pp. 402-408, 2001.

[34] Q. Gao, J. Zhao, L. Song et al., "Molecular cloning, characterization and expression of heat shock protein 90 gene in the haemocytes of bay scallop Argopecten irradians," Fish and Shellfish Immunology, vol. 24, no. 4, pp. 379-385, 2008.

[35] K. Richter and J. Buchner, "Hsp90: chaperoning signal transduction," Journal of Cellular Physiology, vol. 188, no. 3, pp. 281290, 2001.

[36] P. Krishna and G. Gloor, "The Hsp90 family of proteins in Arabidopsis thaliana," Cell Stress and Chaperones, vol. 6, no. 3, pp. 238-246, 2001.

[37] H. E. Ireland, S. J. Harding, G. A. Bonwick, M. Jones, C. J. Smith, and J. H. H. Williams, "Evaluation of heat shock protein 70 as a biomarker of environmental stress in Fucus serratus and Lemna minor," Biomarkers, vol. 9, no. 2, pp. 139-155, 2004. 

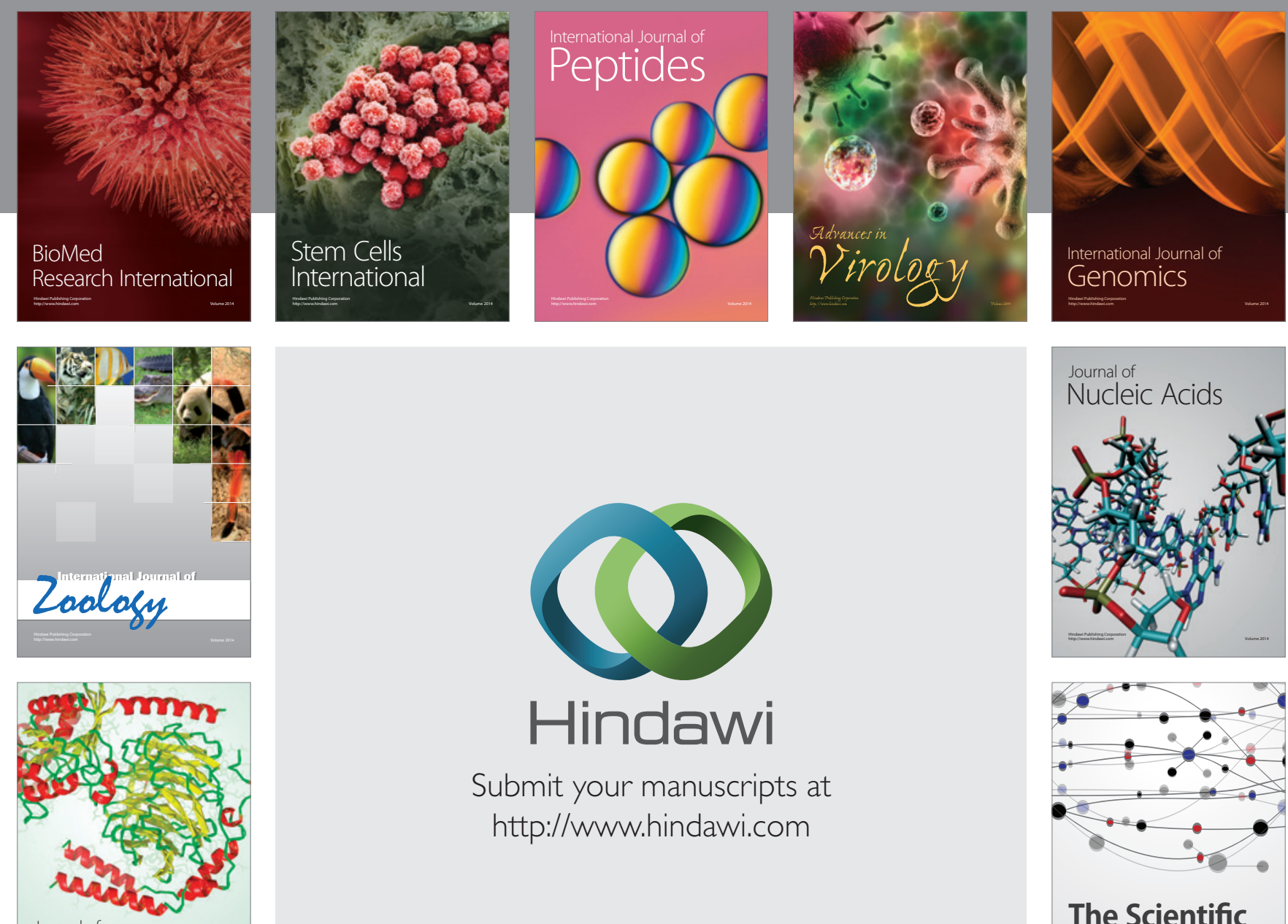

Submit your manuscripts at

http://www.hindawi.com

Journal of
Signal Transduction
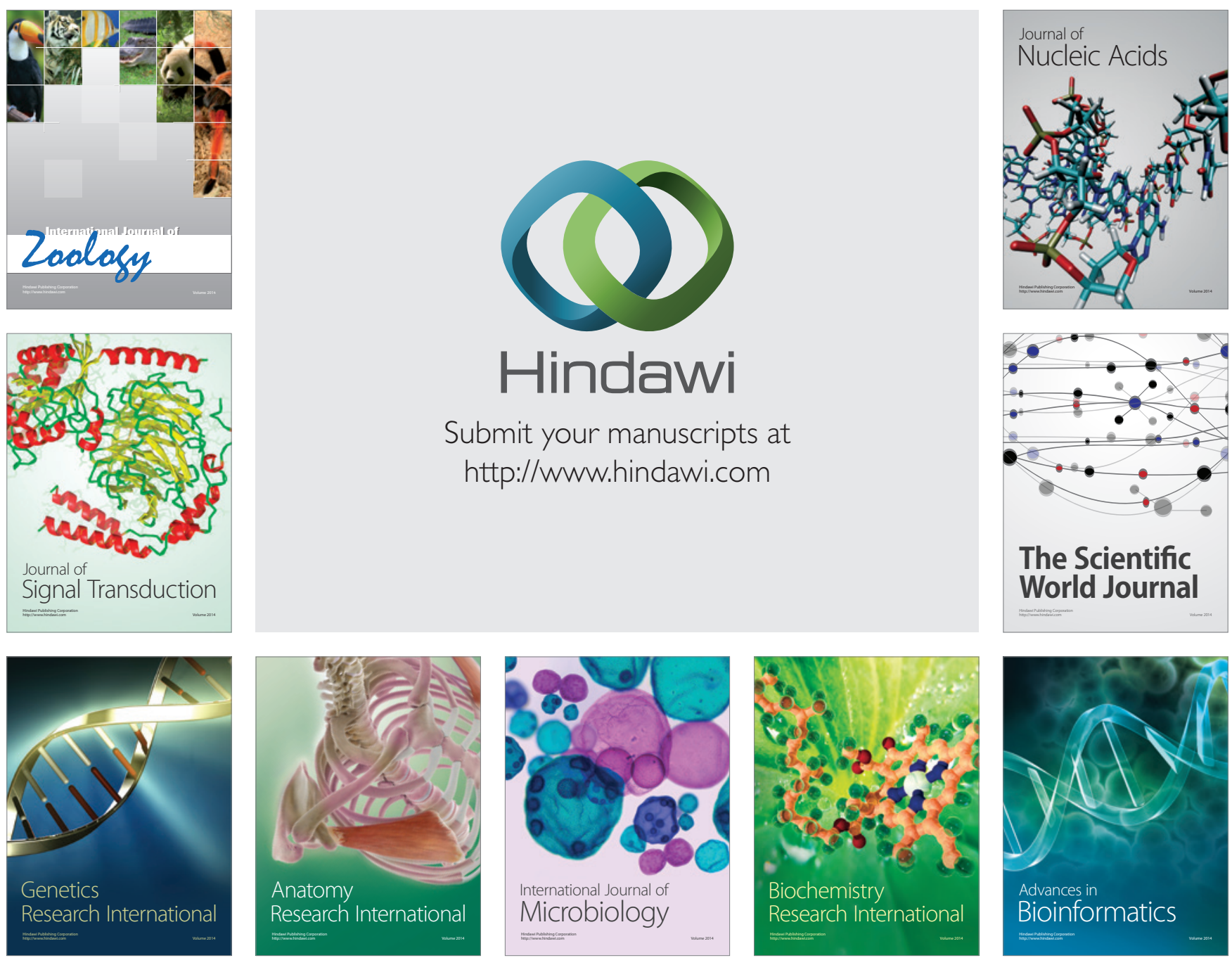

The Scientific World Journal
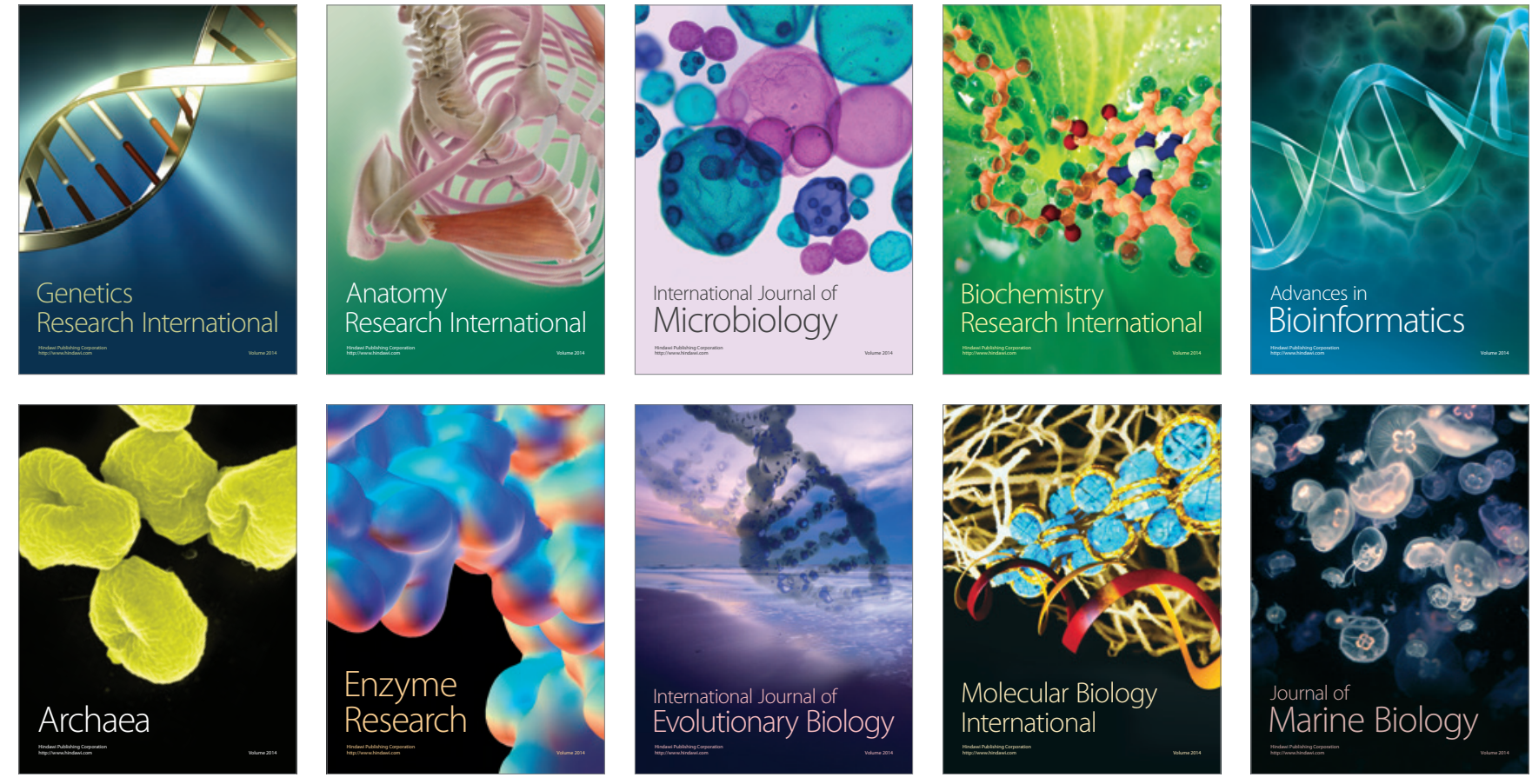